\title{
ANALYSIS OF THE EFFECTS OF DEMOGRAPHIC VARIABLES AND CHARACTERISTICS OF THE FACEBOOK SOCIAL NETWORK ON PURCHASING
}

\author{
Marija Vranješ* \\ Novi Sad School of Business \\ Novi Sad, Republic of Serbia \\ Dragoljub Jovičić \\ Novi Sad School of Business \\ Novi Sad, Republic of Serbia \\ Dragana Gašević \\ Novi Sad School of Business \\ Novi Sad, Republic of Serbia
}

\begin{abstract}
Summary: The aim of the paper is to analyze the effect of demographic features and Facebook usage characteristics on making a purchase. In this regard, descriptive statistics measures, reliability analysis, independent sample $t$-tests, one-factor and twofactor analysis of variance were used. The results of the study show that there are no statistically significant differences in gender or age regarding the purchase decision. Also, statistically significant differences in this regard are not detected in the case of variables concerning the characteristics of use of the social network Facebook (mode of access to the social network, length of use, frequency of logging in to the account, average time spent on the social network mentioned, and frequency of updating the account). A statistically significant result was observed only in the case of level of education. It has been found that people with the highest level of education (master / $P h D)$ are more likely to make purchases (influenced by Facebook promotion), compared to persons with a bachelor's degree and secondary education. In this regard, the research results suggest the management should focus marketing efforts towards people with the highest level of education. In addition, the problem associated with low levels of purchase of other groups of respondents has been identified, which requires further adaptation and improvement of promotional strategies.
\end{abstract}

Keywords: promotion on social networks, Facebook, purchasing

JEL classification: $M 310$

\footnotetext{
*vranjesmarija.vps@gmail.com
} 


\title{
ANALIZA EFEKATA DEMOGRAFSKIH VARIJABLI I KARAKTERISTIKA UPOTREBE DRUŠTVENE MREŽE FACEBOOK NA KUPOVINU
}

\begin{abstract}
Sažetak: Cilj rada je da analizira efekat demografskih karakteristika i karakteristika upotrebe društvene mreže Facebook na kupovinu. S tim u vezi, korišćene su mere deskriptivne statistike, analiza pouzdanosti, t-test nezavisnih uzoraka, jednofaktorska $i$ dvofaktorska analiza varijanse. Rezultati istraživanja pokazuju da ne postoje polne niti starosne statistički značajne razlike u pogledu donošenja odluke o kupovini. Takođe, statistički značajne razlike, u tom smislu, nisu otkrivene ni u slučaju varijabli koje se tiču karakteristika upotrebe društvene mreže Facebook (način prustupa društvenoj mreži, dužina korišćenja, učestalost prijavljivanja na nalog, prosečno provedeno vreme na pomenutoj društvenoj mrě̌i $i$ učestalost ažuriranja naloga). Statistički zanačajan rezultat uočen je samo u slučaju stepena stručne spreme. Utvrđeno je da osobe sa najvišim nivoom obrazovanja (master/magistar/doktor nauka) češće obavljaju kupovinu (nastalu pod uticajem Facebook promocije), u odnosu na osobe sa visokom i srednjom stručnom spremom. S tim u vezi, rezultati istraživanja sugerišu menadžmentu smer $u$ kom treba da usmeri marketinške napore - osobe sa najvišim nivoom obrazovanja, ali $i$ identifikuju problem u vezi sa niskim nivoom kupovine ostalih grupa ispitanika, što dalje zahteva adaptiranje i unapređivanje promotivnih strategija.
\end{abstract}

Ključne reči: promocija na društvenim mrežama, Facebook, kupovina

\section{INTRODUCTION}

The modern business conditions are characterized by a remarkable complexity, created by a number of factors. One of the most significant is the globalization process that has completely changed the concept of competition. In the context of global competition, the main challenge is to achieve competitiveness. In this regard, management should focus on marketing concept, business orientation towards the customer, positioning in the consumer awareness, branding, innovation, etc. All of the above can be consolidated through promotion on social networks. In connection with this, the subject of this paper is the promotion on social network Facebook. We shall define and analyze the characteristics of this type of advertising, and highlight the main guidelines for conducting the promotional activities on the mentioned network. The main aim of the paper is to analyze the effects of demographic characteristics as well as the usage characteristics of this social network on the purchase itself. 


\section{REVIEW OF LITERATURE}

\subsection{PROMOTION THROUGH SOCIAL NETWORKS}

Digital marketing, as an area of marketing, is becoming an increasingly topical subject. Quinton and Simkin (2017) state that this form of marketing enables the consumers of businesses and other stakeholders to create, access and share digital content. One of the basic tools of digital communication is also a social media marketing such as Facebook, Instagram, LinkedIn, Pinterest, Snapchat and Twitter. It is the media that should encourage audience participation, that is, the participation of the users, their interaction as well as content sharing, all with the aim of increasing awareness of a particular brand (Chaffey and EllisChadwick, 2019). Blogs, Facebook and LinkedIn are widely accepted by organizations today, and social network assimilation is experiencing exponential growth (Bharati, Zhang and Chaudhury, 2014). In this way, there is a huge potential for advertising that brings numerous advantages. In this regard, Charlesworth $(2014$, p.32) defines three main goals of online marketing activities: brand development, revenue generation and customer service and support improvement. In line with the above, the author points out that, through online presence, it is possible to supplement the efforts carried out off-line by an organization, and thus improve the business.

Compared to other forms of promotion on the Internet, the promotion through social networks is experiencing the greatest increase. In this regard, it is anticipated that investment in mobile promotion will experience the greatest growth. On the other hand, investments in promotion on desktops, newspapers and magazines will see the biggest decrease (Krstić and Đurđević, 2017). Based on the above, it can be concluded that advertising on social networks is, in fact, no longer just an option, but a necessity.

Advertising on the social networking site Facebook brings many advantages, but also some limitations, which will be outlined below.

First of all, the modern consumer is aware that time is a resource that is not renewed. For this reason, they appreciate fast and easy communication, quality content and the availability of products and information. Social networks are very helpful with all of this.

Furthermore, a man is a social being and as such strives for social inclusion. With the advent of social networks, this human need has taken a whole new form. In this sense, today, consumers want closer, interactive communication. They want to be on a first-name basis with the brand and allow it to be the part of their daily routine. 
Advertiser benefits primarily relate to the characteristics of Facebook users themselves, i.e. the audience targeted by the advertising. Audiences present on social networks are more active, often in search for information, which is why there is more understanding for promotional messages. In contrast, classic forms of promotion, such as a promotional video on television, interrupt a potential consumer in an activity that they are focused on (e.g. watching a film) and provide them with information that they are not looking for at a given moment.

In addition, the use of social networks for business purposes can have a significant impact, regardless of the activity of the company, as well as the size of the company. Moreover, promotion on social networks is even more significant for small businesses, since in this case advertising budgets are often very modest. In this way, small businesses are able to reap significant benefits with relatively low investment.

Finally, according to World Bank reports, the process of digitization is leading to a fall in data collection costs, but also improvement of the efficiency through higher speed of service delivery. In addition, the whole process leads to the development of an innovative concept as well as the creation of potential jobs (Vătămănescu, Nistoreanu and Mitan, 2017).

When it comes to the restrictions on promotion through social networks, Chiu, Wang, Fang and Huang (2014) cite certain risks that consumers face. First of all, there is a financial risk, then the risk related to product performance, the consumer privacy policy itself, and finally, the product delivery problems.

\subsection{FACEBOOK ADVERTISING GUIDELINES}

When it comes to creating an effective Facebook advertising strategy, it should be noted that constant up-to-date information on new trends in this dynamic field is necessary. Regardless of the constant emphasizing of the new guidelines for the development of online advertising strategies, some of them are constant.

Above all, it is of the utmost importance to offer high quality content to the user. It can be informative, entertaining, etc. The bottom line is that the user has some kind of benefit from that content. In such a situation, users are more motivated to press the "like button", to comment on it and to share it.

Furthermore, "good photography" is something that catches your eye, attracts attention, and contributes to better positioning and more reactions. Social media photography should not look like a catalog, with a monochrome background and an object in the middle, but it is necessary to create an ambience" (Maglov, 2017, p.128). 
90 | ANALYSIS OF THE EFFECTS OF DEMOGRAPHIC VARIABLES AND CHARACTERISTICS OF THE FACEBOOK SOCIAL NETWORK ON PURCHASING

In addition, videos are becoming more current. It is very important that they are realistic, informative, accompanied by a textual story and relatively short (Maglov, 2017).

In addition to the quality of the post itself, when advertising on Facebook, it is necessary to take into account the time of posting the post. In this regard, Treadaway and Smith (2010) point out that it would be ideal to post it after working hours, very late at night or on Sundays, since there is less exposure to competing publications then.

For Facebook promotion, hash-tags also play a big role. These are very significant entities on the global network. It is up to the company to choose a unique hash-tag to accompany each of their campaigns, making it easier to track results and improve page reach (SEMrush, 2016).

Finally, it is also necessary to target your audience in order to increase the effectiveness of your campaign. In this regard, Facebook offers one of the most powerful and free tools of Audience Insights that provides the ability to target users by location, age, gender, language, and more (Fairbrother, 2019).

\subsection{PURCHASE INFLUENCED BY FACEBOOK PROMOTION}

All the activities mentioned in the previous part of the paper can contribute to connecting the consumers with the brand and thus make a specific brand the first choice of consumers. This is also confirmed by a study conducted by Duffet (2015), according to which the use of social networks and promoting through them influences the formation of consumer attitudes and the initiation of purchase. Similarly, Yang (2012) states that promotional messages on the Facebook social network enhance consumer attitudes towards a particular brand as well as purchase intentions.

Namely, the attitude towards advertising has been widely researched in the last few decades and it has been found that consumer attitude towards advertising has a direct influence on attitude towards brand (Duffet, 2014). Accordingly, Yoo, Kim and Stout (2010) even state that attitudes towards advertising are considered to be an effective measure of advertising effectiveness. Furthermore, consumer attitudes determine their intentions, which ultimately influence the actual consumer buying behavior. Reasonable Action Theory -TRA (Ajzen and Fishbein, 1980), as well as Theory of Planned Behavior - TPB (Ajzen, 1991) both deal with the relationship between consumer attitudes, intentions and behavior. Therefore, the positive attitude of users towards advertising on social networks has a positive influence on their purchasing behavior, as discussed by the authors: Mir (2012); Wolin, Korgaonkar and Lund (2002); Wang and Sun (2010). On the other hand, there are opposite views. In this regard, Maxwell 
(2013) states that many consumers through social networks are, in fact, merely collecting information while still favoring shopping at real establishments.

In accordance with the defined research objective and review of relevant literature, the following hypotheses are defined:

H1: When it comes to purchases (made under the influence of Facebook promotion), there is a statistically significant difference between different groups of respondents, divided by demographic characteristics.

H1a: When it comes to purchases (made under the influence of Facebook promotion), there is a statistically significant difference between men and women.

H1b: When it comes to purchases (made under the influence of Facebook promotion), there is a statistically significant difference among the different age groups of respondents.

H1c: When it comes to purchases (made under the influence of Facebook promotion), there is a statistically significant difference between the different groups of respondents, divided by level of education.

H2: When it comes to purchases (made under the influence of Facebook promotion), there is a statistically significant difference between the different groups of respondents, divided by the characteristics of using Facebook.

H2a: When it comes to purchases (influenced by Facebook promotion)., there is a statistically significant difference between the different groups of respondents, divided by the way they access the social network Facebook.

H2b: When it comes to purchases (influenced by Facebook promotion), there is a statistically significant difference between the different groups of respondents, divided by the length of time they have a Facebook account.

H2c: When it comes to purchases (influenced by Facebook promotion), there is a statistically significant difference between the different groups of respondents, divided by the frequency of logging into a Facebook account.

H2d: When it comes to purchases (influenced by Facebook promotion), there is a statistically significant difference between the different groups of respondents, divided by the time spent on the social network Facebook.

H2e: When it comes to purchases (influenced by Facebook promotion), there is a statistically significant difference between the different groups of respondents divided by the frequency of Facebook profiles updates. 


\section{RESEARCH METHODOLOGY}

In order to examine the effect of demographic variables and characteristics of the use of the Facebook social network on the formation of differences in terms of making a purchase decision, empirical research was conducted using a survey method. The data were collected during August 2018 on a sample of 181 respondents through an online questionnaire that was forwarded to respondents through Facebook.

The questionnaire was designed in 3 parts. The first part of the questionnaire covers demographics. The second part deals with the characteristics of the use of the social network Facebook by the surveyed users. The third part of the questionnaire consists of 4 claims connected to the purchase itself (made under the influence of Facebook promotion). The respondents expressed their degree of agreement with these claims on a five-point Likert scale. The basis for the design of the questionnaire was the research conducted by Duffett (2015), and all the claims made in that research were adapted for the purpose of carrying out this specific research.

The analysis of the collected data was performed using the SPSS statistical package, using descriptive statistical analysis, Cronbach's alpha coefficient analysis, t-test, one-factor and two-factor variance analysis. In the first step, a descriptive statistical analysis was performed and the arithmetic mean and standard deviation for each claim were calculated. In this way, purchase attitudes (generated under the influence of promotion on the social network Facebook) were measured and homogeneity of the views of users of this network was determined. The reliability, that is, the internal consistency of the claims, was measured on the basis of the Cronbach's alpha value.

In the next step, a t-test and one-factor analysis of variance were conducted to investigate the individual effect of demographic variables (gender, age, educational attainment) and variables concerning the characteristics of use of the Facebook social network (mode of access to the social network Facebook, length of use of the social network Facebook networks, the frequency of logging into a Facebook account, the average time spent on the Facebook social network, and the frequency of updating a Facebook account) to form differences in terms of making a purchasing decision.

Finally, a two-factor analysis of the variance of the different groups of respondents divided by level of education was conducted, since only in this case statistically significant differences in terms of purchase emerged. This analysis sought to determine whether a person's gender and age alters the effect of their education on purchasing. 
Table 1

Sample structure $(n=181)$

\begin{tabular}{|c|c|c|c|}
\hline \multicolumn{2}{|c|}{ Demographic characteristics } & $\begin{array}{c}\text { Number of } \\
\text { respondents (n) }\end{array}$ & $\begin{array}{c}\text { Percentage } \\
(\%)\end{array}$ \\
\hline \multirow{2}{*}{ Gender } & Men & 53 & 29,3 \\
\hline & Women & 128 & 70,7 \\
\hline \multirow{4}{*}{ Age } & Up to 25 years & 47 & 26,0 \\
\hline & $26-35$ years & 59 & 32,6 \\
\hline & $36-45$ years & 52 & 28,7 \\
\hline & 46 and over years & 23 & 12,7 \\
\hline \multirow{5}{*}{$\begin{array}{l}\text { Professional } \\
\text { qualifications }\end{array}$} & Primary education degree & 2 & 1,1 \\
\hline & Secondary education degree & 70 & 38,7 \\
\hline & $\begin{array}{l}\text { Post-secondary non-academic } \\
\text { degree }\end{array}$ & 32 & 17,7 \\
\hline & $\begin{array}{l}\text { 4-year Bachelor's academic } \\
\text { degree }\end{array}$ & 49 & 27,1 \\
\hline & Post graduate degrees $\mathrm{MSc} / \mathrm{PhD}$ & 28 & 15,5 \\
\hline \multicolumn{4}{|c|}{ Facebook usage characteristics } \\
\hline \multirow{3}{*}{ Access } & Mobile device & 141 & 77,9 \\
\hline & $\mathrm{PC}$ & 15 & 8,3 \\
\hline & Mobile device and PC & 25 & 13,8 \\
\hline \multirow{5}{*}{ Length of usage } & $<1$ year & 1 & 0,6 \\
\hline & $1-2$ years & 1 & 0,6 \\
\hline & 2-3 years & 3 & 1,7 \\
\hline & 3-5 years & 16 & 8,8 \\
\hline & $>5$ years & 160 & 88,4 \\
\hline \multirow{5}{*}{ Log-on frequency } & Daily & 163 & 90,1 \\
\hline & 2-4 a week & 14 & 7,7 \\
\hline & Once a week & 2 & 1,1 \\
\hline & 2-4 a month & 1 & 0,6 \\
\hline & Once a month & 1 & 0,6 \\
\hline \multirow{5}{*}{ Log-on duration } & $<1$ hour & 116 & 64,1 \\
\hline & $1-2$ hours & 33 & 18,2 \\
\hline & 2-3 hours & 19 & 10,5 \\
\hline & 3-4 hours & 4 & 2,2 \\
\hline & $>5$ hours & 9 & 5,0 \\
\hline \multirow{5}{*}{$\begin{array}{l}\text { Profile update } \\
\text { incidence }\end{array}$} & Daily & 7 & 3,9 \\
\hline & 2-4 a week & 18 & 9,9 \\
\hline & Once a week & 16 & 8,8 \\
\hline & 2-4 a month & 25 & 13,8 \\
\hline & Once a month & 115 & 63,5 \\
\hline
\end{tabular}


Note. Calculated by the authors

Based on the data in Table 1, it is concluded that women $(70,7 \%)$ are more represented than men $(29,3 \%)$. Regarding the structure of the respondents by age, it is noted that the majority of respondents belonged to the group of people between 26 and 35 years $(32,6 \%)$, while the smallest number was 46 and older $(12,7 \%)$. By dividing the sample by qualification, it is noticed that the majority of respondents have secondary school $(38,7 \%)$, while the fewest with primary school $(1,1 \%)$.

When looking at the characteristics of the use of Facebook social network by the respondents, it is concluded that users most often access their account through mobile phones $(77,9 \%)$, while the lowest number of those who do it is using the computers $(8,3 \%)$. Among the respondents, the most numerous were those who opened an account on this social network more than 5 years ago $(88,4 \%)$, and the least numerous are new users, i.e. those who have had an account for less than a year $(0,6 \%)$ or between one year and two days $(0,6 \%)$. When it comes to the frequency of logging into a Facebook account, the majority of respondents stated that they $\log$ in daily $(90,1 \%)$, while the smallest number of them said that they do so $2-4$ times a month $(0,6 \%)$ or only once a month $(0,6 \%)$. Although most respondents log into their account on a daily basis, most of them stay logged for a relatively short period. Namely, as many as $64.1 \%$ spend less than an hour on Facebook, while the smallest number of people spend 3-4 hours $(2,2 \%)$. Finally, when it comes to the frequency of Facebook profile updates, the majority of respondents do so only once a month $(63,5 \%)$, while the least common $(3,9 \%)$ are those who update content on a daily basis.

Since Facebook is a social network that has existed for 15 years, it is concluded that it is well known to its users. All generations are siding up with it, and unlike other social networks, such as Instagram, it is not considered a network reserved for the "younger population". As the mobile app has been updated in recent years, there has been a massive reorientation of users to access this network via a mobile phone. This practical solution made it easy to access the network at any time. In this way, users are enabled to perform multiple activities simultaneously. In this regard, Crosman (2008) states that nowadays, thanks to mobile phones, it is possible to access the internet, social networks, television, on the move, as well as search for the information on the basis of which the purchase decision is made. It is this ease of access that prompts users to check the news daily, but retention and activity are slowly declining, as evidenced by the descriptive indicators listed in Table 1 . As the popularity of other social networks is growing, most notably Instagram, users are slowly shifting their focus to this more dynamic and "visual" network. 
After calculating the abovementioned descriptive statistics, it was observed that in one category of variables related to the length of use of the social network Facebook and the frequency of logging into a Facebook account, there is only one person. Since such variables are not suitable for statistical analysis, the respondents from this group were combining with the respondents in the adjacent categories. Therefore, the variable length of use of the social network Facebook, after this refinement, is reduced to three categories: up to 3 years, from 3 to 4 years and over 5 years. The variable frequency of logging into a Facebook account is also divided into three categories: daily, 2-4 times a week, once a week and less frequently.

\section{RESULTS OF THE RESEARCH}

Using the descriptive statistics, the values of the arithmetic mean and the standard deviation were calculated based on the 4 items that measured the purchase generated by Facebook promotion. For all the items, respondents expressed high levels of willingness to buy, in terms of making a purchasing decision.

Based on the results of the aforementioned analysis, it was concluded that the respondents generally agree with the given statements describing the purchase. The most negative attitude is expressed for the statement: Advertising on the social network Facebook makes me even more loyal to the chosen brand (arithmetic mean $=2,33$ ), while the most favorable attitude of the respondents is expressed in the case of the statement: Advertising on the social network Facebook positively influences my decision to buy (arithmetic mean $=2,61$ ).

Table 2

Descriptive statistics

\begin{tabular}{|l|c|c|}
\hline \multicolumn{1}{|c|}{ Statements } & Mean & $\begin{array}{c}\text { Standard } \\
\text { Deviation }\end{array}$ \\
\hline I buy products / services that are advertised on Facebook. & 2,44 & 1,233 \\
\hline $\begin{array}{l}\text { I use many of the products that are promoted } \\
\text { on Facebook. }\end{array}$ & 2,34 & 1,202 \\
\hline $\begin{array}{l}\text { Advertisements on Facebook affect my purchase } \\
\text { behavior positively. }\end{array}$ & 2,61 & 1,131 \\
\hline $\begin{array}{l}\text { Advertisements on Facebook help make me loyal } \\
\text { to the promoted products. }\end{array}$ & 2,33 & 1,143 \\
\hline
\end{tabular}

Note. Calculated by the authors.

The lowest degree of disagreement among the respondents was obtained (standard deviation $=1,131$ ) for the statement: Advertisements on Facebook affect my purchase behavior positively. The highest degree of disagreement among the respondents (with standard deviation $=1,233$ ) was observed with the SCHOOL OF BUSINESS, 1/2019, 86-106 
96 | ANALYSIS OF THE EFFECTS OF DEMOGRAPHIC VARIABLES AND CHARACTERISTICS OF THE FACEBOOK SOCIAL NETWORK ON PURCHASING

statement: I buy products/services that are promoted on the social network Facebook (Table 2). All of the above statements can be grouped into the variable "Purchase". In order to test the reliability and internal consistency of the findings, the Cronbach's alpha coefficient was calculated. The values of the mentioned coefficient can range from 0 to 1 , with values above 0.7 indicating appropriate reliability and internal consistency of the findings (Nunnally, 1978; George and Mallery, 2003; Hair, Bush and Ortinau, 2009; Maree, 2007). Since the Cronbach's alpha coefficient is 0.849 , it is concluded that there is adequate reliability and internal consistency of the findings that make up the measurement scale, i.e. variable Purchase.

In the next step, an independent samples t-test was conducted to compare the mean values of the continuous variable for the two different groups. This way, we wanted to determine if there is a statistically significant gender difference when it comes to making a purchasing decision. The results are presented in Table 3 and Table 4.

Purchases made by men and women were compared on the basis of a t-test of independent samples. It was found that there was no statistically significant difference in results in men $(\mathrm{M}=2,27 ; \mathrm{SD}=0,83)$ and women $(\mathrm{M}=2,50 ; \mathrm{SD}=$ $1,03) ; \mathrm{t}(178)=-1,39, \mathrm{p}=0,17$ (mutually).

Table 3

Descriptive indicators

\begin{tabular}{|c|c|c|c|c|c|}
\hline & Gender & $\mathbf{N}$ & Mean & $\begin{array}{c}\text { Standard } \\
\text { Deviation }\end{array}$ & $\begin{array}{c}\text { Std. Error } \\
\text { Mean }\end{array}$ \\
\hline \multirow{3}{*}{ Purchase } & Men & 52 & 2,27 & 0,829 & 0,115 \\
& Women & 128 & 2,50 & 1,027 & 0,091 \\
\hline
\end{tabular}

Note. Calculated by the authors.

In addition, a small difference was found between the mean values of the characteristics by groups (mean difference $=-0,22 ; 95 \% \mathrm{CI}$ : $-0,54$ to 0,09 ). This difference was determined using the eta square indicator, which takes a value between 0 and 1 and represents the proportion of variance in the dependent variable, explained by the independent variable. Based on the formula for calculating this square:

eta square $=\frac{t^{2}}{t^{2}+\left(N_{1}+N_{2}-2\right)}$

a value of 0.01 was obtained, which is a small influence. Cohen regards " 0.01 as small; 0.06 as medium and 0.14 as high influence" (Cohen, 1988, p.284). 
Table 4

T-test of non-independent samples

\begin{tabular}{|c|c|c|c|}
\hline & & & Purchase \\
\hline \multirow{2}{*}{$\begin{array}{l}\text { Levene's Test for Equality of } \\
\text { Variances }\end{array}$} & \multicolumn{2}{|l|}{$\mathrm{F}$} & 2,93 \\
\hline & \multicolumn{2}{|l|}{ Sig. } & 0,089 \\
\hline \multirow{7}{*}{ t-test for Equality of Means } & \multicolumn{2}{|l|}{$\mathrm{t}$} & $-1,386$ \\
\hline & \multicolumn{2}{|l|}{$\mathrm{df}$} & 178 \\
\hline & \multicolumn{2}{|l|}{ Sig. (2-tailed) } & 0,168 \\
\hline & \multicolumn{2}{|c|}{ Mean Difference } & $-0,222$ \\
\hline & \multicolumn{2}{|c|}{ Std. Error Difference } & 0,16 \\
\hline & \multirow{2}{*}{$\begin{array}{l}95 \% \text { CI of the } \\
\text { Difference }\end{array}$} & Lower & $-0,538$ \\
\hline & & Upper & 0,094 \\
\hline
\end{tabular}

Note. Calculated by the authors.

In order to examine differences regarding the average value of a dependent continuous variable, in the case of an independent variable (grouping) with three or more levels, one-factor analysis of variance is applied. One-way analysis of variance compares variance between groups with variance within each group.

In this regard, in the next step, a one-factor analysis of variance was performed in order to investigate the individual effect of the remaining demographic variables (age, educational level) and the variables concerning the characteristics of the use of the Facebook social network (method of access to the Facebook social network, length of use of the Facebook social network, frequency of logging into Facebook account, average time spent on Facebook social network, and frequency of updating Facebook account) on purchase. The results of the analysis are presented in Table 5 and Table 6.

Before conducting a one-factor analysis of variance, the assumption of homogeneity of variance was tested using the Leven test, which examines equality of variance in scores, in each of the groups of variables analyzed. Since for each variable the Leven test showed a significance greater than 0.05 , the assumption was not violated in any particular case.

In the following steps, one-factor analysis of variance was conducted to examine differences in purchasing decisions in the case of the following variables at 3 or more levels: age, level of education, mode of access to the Facebook social network, length of use of the Facebook social network, 
98 | ANALYSIS OF THE EFFECTS OF DEMOGRAPHIC VARIABLES AND CHARACTERISTICS OF THE FACEBOOK SOCIAL NETWORK ON PURCHASING

frequency of reporting to Facebook account, average time spent on Facebook social network, frequency of updating Facebook account.

The results of individual one-factor analyses of variance showed that there was no statistically significant difference in terms of age, mode of access to Facebook social network, length of use of Facebook social network, frequency of logging into Facebook account, average time spent on Facebook social network and frequency of updating Facebook account.

A one-factor analysis of variance showed a statistically significant result only in the case of level of education. Specifically, this analysis explores the impact of a degree acquired on purchasing. The respondents were divided into 5 groups (group 1: Primary education degree; group 2: secondary education degree; group 3: Post-secondary undergraduate non-academic degrees; group 4: 4-year Bachelor academic degree group 5: Post-graduate degrees: master/PhD).

A statistically significant difference was found at the level of $p<0,05$ in the results of 5 groups of respondents divided by the degree they acquired: $F$ (4, $175)=3,7 ; p=0,01$. The real difference between the mean values of the groups is the mean level.

Post hoc tests were performed to obtain the final interpretation of the results. They consist of comparisons designed to compare all different combinations of treated groups (Field, 2009). Subsequent comparisons were made using Tukey's HSD test. The results indicate that the mean of Group 5: / master / $\mathrm{PhD}(\mathrm{M}=$ $3,02 ; \mathrm{SD}=1,132)$ is significantly different from the mean of Group 2: Secondary Education $(\mathrm{M}=2,23 ; \mathrm{SD}=0,828)$ as well as mean of group 4: 4year Bachelor academic degree group $(M=2,35 ; S D=0,916)$. In other cases, there is no significant difference. The magnitude of this difference is expressed by the eta square indicator, which compares the sum of squares of deviations of different groups with the total sum of squares. In this particular case, the eta square is 0,08 , which is, according to Cohen's criterion, classified as mean influence. 
Table 5

Descriptive indicators

\begin{tabular}{|c|c|c|c|c|c|c|c|c|c|}
\hline & \multirow[b]{2}{*}{$\mathbf{N}$} & \multirow[b]{2}{*}{ Mean } & \multirow[b]{2}{*}{$\begin{array}{l}\text { Std. } \\
\text { Deviat }\end{array}$} & \multirow[b]{2}{*}{$\begin{array}{l}\text { Std. } \\
\text { Error }\end{array}$} & \multicolumn{2}{|c|}{ 95\% CI for Mean } & \multirow[b]{2}{*}{ Min } & \multirow[b]{2}{*}{ Max } \\
\hline & & & & & & $\begin{array}{l}\text { Lower } \\
\text { Bound }\end{array}$ & $\begin{array}{l}\text { Upper } \\
\text { Bound }\end{array}$ & & \\
\hline \multirow{5}{*}{$\sum_{\infty}^{\infty}$} & Up to 25 years & 47 & 2,37 & 0,953 & 0,139 & 2,09 & 2,65 & 1 & 5 \\
\hline & $26-35$ years & 59 & 2,51 & 1,042 & 0,136 & 2,24 & 2,78 & 1 & 5 \\
\hline & $36-45$ years & 52 & 2,59 & 0,946 & 0,131 & 2,32 & 2,85 & 1 & 5 \\
\hline & 46 and over years & 22 & 1,99 & 0,829 & 0,177 & 1,62 & 2,36 & 1 & 4 \\
\hline & Total & 180 & 2,43 & 0,977 & 0,073 & 2,29 & 2,58 & 1 & 5 \\
\hline \multirow{6}{*}{ } & Primary edu. degree & 2 & 2,13 & 0,177 & 0,125 & 0,54 & 3,71 & 2 & 2 \\
\hline & Second. edu. degree & 70 & 2,23 & 0,828 & 0,099 & 2,03 & 2,43 & 1 & 4 \\
\hline & $\begin{array}{l}\text { Post-secondary non- } \\
\text { academic degree }\end{array}$ & 31 & 2,51 & 1,087 & 0,195 & 2,11 & 2,91 & 1 & 5 \\
\hline & $\begin{array}{l}\text { 4-year Bachelor } \\
\text { academic degree }\end{array}$ & 49 & 2,35 & 0,916 & 0,131 & 2,09 & 2,62 & 1 & 5 \\
\hline & M.Sc./PhD & 28 & 3,02 & 1,132 & 0,214 & 2,58 & 3,46 & 1 & 5 \\
\hline & Total & 180 & 2,43 & 0,977 & 0,073 & 2,29 & 2,58 & 1 & 5 \\
\hline \multirow{4}{*}{ 选 } & Mobile device & 141 & 2,45 & 0,976 & 0,082 & 2,29 & 2,61 & 1 & 5 \\
\hline & $P C$ & 15 & 2,10 & 0,755 & 0,195 & 1,68 & 2,52 & 1 & 4 \\
\hline & Mobile device andPC & 24 & 2,52 & 1,093 & 0,223 & 2,06 & 2,98 & 1 & 5 \\
\hline & Total & 180 & 2,43 & 0,977 & 0,073 & 2,29 & 2,58 & 1 & 5 \\
\hline \multirow{4}{*}{ 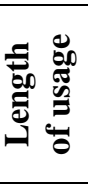 } & $<3$ years & 5 & 1,80 & 0,570 & 0,255 & 1,09 & 2,51 & 1 & 3 \\
\hline & 3-5 years & 16 & 2,38 & 1,017 & 0,254 & 1,83 & 2,92 & 1 & 4 \\
\hline & $>5$ years & 159 & 2,46 & 0,981 & 0,078 & 2,30 & 2,61 & 1 & 5 \\
\hline & Total & 180 & 2,43 & 0,977 & 0,073 & 2,29 & 2,58 & 1 & 5 \\
\hline \multirow{4}{*}{ 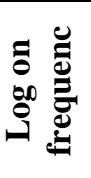 } & Daily & 162 & 2,41 & 0,941 & 0,074 & 2,26 & 2,55 & 1 & 5 \\
\hline & 2-4 a week & 14 & 2,89 & 1,296 & 0,346 & 2,14 & 3,64 & 1 & 5 \\
\hline & Once a week & 4 & 1,88 & 0,854 & 0,427 & 0,52 & 3,23 & 1 & 3 \\
\hline & Total & 180 & 2,43 & 0,977 & 0,073 & 2,29 & 2,58 & 1 & 5 \\
\hline \multirow{6}{*}{ 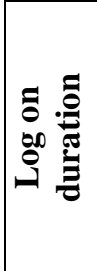 } & $<1$ hour & 116 & 2,34 & 0,910 & 0,085 & 2,17 & 2,51 & 1 & 5 \\
\hline & 1-2 hours & 33 & 2,67 & 1,060 & 0,185 & 2,29 & 3,04 & 1 & 5 \\
\hline & 2-3 hours & 18 & 2,76 & 1,045 & 0,246 & 2,24 & 3,28 & 1 & 5 \\
\hline & 3-4 hours & 4 & 1,88 & 0,854 & 0,427 & 0,52 & 3,23 & 1 & 3 \\
\hline & $>5$ hours & 9 & 2,36 & 1,263 & 0,421 & 1,39 & 3,33 & 1 & 5 \\
\hline & Total & 180 & 2,43 & 0,977 & 0,073 & 2,29 & 2,58 & 1 & 5 \\
\hline \multirow{5}{*}{ 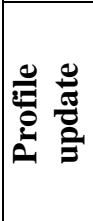 } & Daily & 7 & 3,07 & 1,344 & 0,508 & 1,83 & 4,31 & 1 & 5 \\
\hline & 2-4 a week & 17 & 2,43 & 1,041 & 0,253 & 1,89 & 2,96 & 1 & 4 \\
\hline & Once a week & 16 & 2,33 & 0,952 & 0,238 & 1,82 & 2,84 & 1 & 5 \\
\hline & 2-4 a month & 25 & 2,25 & 0,781 & 0,156 & 1,93 & 2,57 & 1 & 4 \\
\hline & Once a month & 115 & 2,45 & 0,985 & 0,092 & 2,27 & 2,63 & 1 & 5 \\
\hline
\end{tabular}

SCHOOL OF BUSINESS, 1/2019, 86-106 
100 | ANALYSIS OF THE EFFECTS OF DEMOGRAPHIC VARIABLES AND CHARACTERISTICS OF THE FACEBOOK SOCIAL NETWORK ON PURCHASING

\begin{tabular}{|l|r|r|r|r|r|r|r|r|r|}
\hline & Total & 180 & 2,43 & 0,977 & 0,073 & 2,29 & 2,58 & 1 & 5 \\
\hline
\end{tabular}

Table 6

One-way ANOVA

\begin{tabular}{|c|c|c|c|c|c|c|}
\hline \multicolumn{2}{|l|}{ Variables } & $\begin{array}{c}\text { Sum of } \\
\text { Squares }\end{array}$ & Df & $\begin{array}{c}\text { Mean } \\
\text { Square }\end{array}$ & $\mathbf{F}$ & Sig. \\
\hline \multirow{3}{*}{ Age } & Between Groups & 6,079 & 3 & 2,026 & \multirow[t]{3}{*}{2,164} & \multirow[t]{3}{*}{0,094} \\
\hline & Within Groups & 164,775 & 176 & 0,936 & & \\
\hline & Total & 170,854 & 179 & & & \\
\hline \multirow{3}{*}{$\begin{array}{l}\text { Professional } \\
\text { qualifications }\end{array}$} & Between Groups & 13,188 & 4 & 3,297 & \multirow[t]{3}{*}{3,660} & \multirow[t]{3}{*}{0,007} \\
\hline & Within Groups & 157,665 & 175 & 0,901 & & \\
\hline & Total & 170,854 & 179 & & & \\
\hline \multirow{3}{*}{ Access } & Between Groups & 1,900 & 2 & 0,950 & \multirow[t]{3}{*}{0,995} & \multirow[t]{3}{*}{0,372} \\
\hline & Within Groups & 168,954 & 177 & 0,955 & & \\
\hline & Total & 170,854 & 179 & & & \\
\hline \multirow{3}{*}{ Length of usage } & Between Groups & 2,153 & 2 & 1,076 & \multirow[t]{3}{*}{1,129} & \multirow[t]{3}{*}{0,326} \\
\hline & Within Groups & 168,701 & 177 & 0,953 & & \\
\hline & Total & 170,854 & 179 & & & \\
\hline \multirow{3}{*}{ Log on frequency } & Between Groups & 4,325 & 2 & 2,163 & \multirow[t]{3}{*}{2,299} & \multirow[t]{3}{*}{0,103} \\
\hline & Within Groups & 166,529 & 177 & 0,941 & & \\
\hline & Total & 170,854 & 179 & & & \\
\hline \multirow{3}{*}{ Log on duration } & Between Groups & 6,103 & 4 & 1,526 & \multirow[t]{3}{*}{1,621} & \multirow[t]{3}{*}{0,171} \\
\hline & Within Groups & 164,751 & 175 & 0,941 & & \\
\hline & Total & 170,854 & 179 & & & \\
\hline \multirow{3}{*}{$\begin{array}{l}\text { Profile update } \\
\text { incidence }\end{array}$} & Between Groups & 3,892 & 4 & 0,973 & \multirow[t]{3}{*}{1,020} & \multirow[t]{3}{*}{0,399} \\
\hline & Within Groups & 166,962 & 175 & 0,954 & & \\
\hline & Total & 170,854 & 179 & & & \\
\hline
\end{tabular}

Note. Calculated by the authors.

Since the one-factor analysis of variance showed a statistically significant difference regarding the decision to purchase in 5 groups related to the degree, in the next step a two-factor analysis of variance of different groups was carried out.

"The advantage of two-factor analysis of variance is that one can examine the underlying impact of each independent variable and the possible impact of their interaction. An interaction effect exists when the influence of one independent variable on the dependent changes, depending on the value of the other independent variable" (Pallant, 2011, p.265).

By the two-factor analysis of variance, the following answers were sought:

1. How do your college degree and gender affect your purchase? That is, does the a person's gender change the impact of their education on shopping? 
2. How do your college degree and age affect your purchase? That is, does a person's age change the impact of his or her education level on shopping?

As in the case of one-factor analysis of variance, the assumption of homogeneity of variance was tested using the Leven test. Given that for each variable, the Leven test showed a significance greater than 0.05 , the assumption was not violated in any particular case.

Table 7

One-way ANOVA

\begin{tabular}{|l|r|r|r|r|r|r|}
\hline \multicolumn{1}{|c|}{ Source } & \multicolumn{1}{c|}{$\begin{array}{c}\text { Type III } \\
\text { Sum of } \\
\text { Squares }\end{array}$} & \multicolumn{1}{c|}{ df } & $\begin{array}{c}\text { Mean } \\
\text { Square }\end{array}$ & \multicolumn{1}{c|}{ F } & \multicolumn{1}{c|}{ Sig. } & $\begin{array}{c}\text { Partial } \\
\text { Eta } \\
\text { Squared }\end{array}$ \\
\hline Corrected Model & $15,900^{\mathrm{a}}$ & 9 & 1,767 & 1,938 & 0,050 & 0,093 \\
Intercept & 227,641 & 1 & 227,641 & 249,746 & 0,000 & 0,595 \\
Gender & 0,055 & 1 & 0,055 & 0,061 & 0,806 & 0,000 \\
Professional & 7,475 & 4 & 1,869 & 2,050 & 0,090 & 0,046 \\
qualifications & 1,809 & 4 & 0,452 &, 496 & 0,739 & 0,012 \\
Gender * & & & & & & \\
Professional & 154,953 & 170 & 0,911 & & & \\
qualifications & 1235,438 & 180 & & & & \\
Error & 170,854 & 179 & & & & \\
Total & $23,765^{\mathrm{b}}$ & 15 & 1,584 & 1,766 & 0,043 & 0,139 \\
Corrected Total & 290,293 & 1 & 290,293 & 323,667 & 0,000 & 0,664 \\
\hline Corrected Model & 4,883 & 3 & 1,628 & 1,815 & 0,146 & 0,032 \\
Intercept & 3,039 & 4 & 0,760 & 0,847 & 0,497 & 0,020 \\
Age & 7,452 & 8 & 0,932 & 1,039 & 0,409 & 0,048 \\
Professional & 147,089 & 164 & 0,897 & & & \\
qualifications & 1235,438 & 180 & & & & \\
Age * Professional & 170,854 & 179 & & & & \\
qualifications & & & & & \\
Error & & & & & \\
Total & & & & & \\
Corrected Total & & & & & \\
\hline
\end{tabular}

Note. Calculated by the authors.

a. R Squared $=0.139$ (Adjusted R Squared $=0,060$ )

b. R Squared $=0.093$ (Adjusted R Squared $=0,045$ )

A two-factor analysis of the variance of different groups explored the influence of gender and educational attainment on purchases made under the influence of SCHOOL OF BUSINESS, 1/2019, 86-106 
102 | ANALYSIS OF THE EFFECTS OF DEMOGRAPHIC VARIABLES AND CHARACTERISTICS OF THE FACEBOOK SOCIAL NETWORK ON PURCHASING

Facebook promotion. The subjects were divided into 5 groups in terms of degree level: (group 1: primary education degree; group 2: secondary education degree; group 3: post-secondary undergraduate non-academic degree; group 4: 4-year Bachelor academic degree 5:Post-graduate degrees: master/PhD). The effect of interaction between gender and educational attainment was not statistically significant $\mathrm{F}(4,170)=0,50 ; \mathrm{p}=0,74$. Major gender influence $\mathrm{F}(1$, $170)=0,06 ; p=0,81$, as well as the main influence of the degree of education $F$ $(4,170)=2,05 ; p=0,09$ did not reach statistical significance.

Subsequently, the impact of age and educational attainment on the purchase made under the influence of Facebook promotion was explored. The effect of the interaction between age and educational attainment was not statistically significant $\mathrm{F}(8,164)=1,04 ; \mathrm{p}=0,41$. Main effect of age $\mathrm{F}(3,164)=1,82 ; \mathrm{p}=$ 0,15 , as well as the main influence of the degree of education $F(4,164)=0,85$; $\mathrm{p}=0,50 \mathrm{did}$ not reach statistical significance.

\section{CONCLUSION}

In today's business environment, promotion through the social networking site Facebook is becoming an increasingly important issue. A systematic approach to this topic is gaining in importance and this is the main reason for further research.

The results of this study show that there are no statistically significant differences in gender, nor age, in the terms of purchase. These findings are consistent with a study conducted by Duffett (2015). In contrast, Bannister, Kiefer and Nellums (2013) found that women had a somewhat more positive attitude towards Facebook advertising, whereas Tailor et al. (2011) found that the most positive attitude toward this type of advertising was found in respondents aged 19-24.

Furthermore, statistically significant differences were not detected even in the case of variables concerning certain characteristics of the use of the Facebook social network (mode of access to the social network, length of use, frequency of logging in to the account). These findings are consistent with research conducted by Duffett (2015). Regarding the remaining usage characteristics, such as average time spent on the aforementioned social network and frequency of account updates, no statistically significant differences were observed. In the case of these characteristics, the results are contrary to the results obtained by Duffet (2015), whose research concludes that these differences are still present. Similarly, Chandra, Goswami and Chouhan (2012) found that regular users (in terms of frequency of account updates) exhibit a positive attitude towards advertising on social networks, due to the fact that it helps in making a purchasing decision. 
In this study, a statistically significant result was observed only in the case of educational attainment, as a demographic characteristic. Specifically, it was found that among the 5 groups of respondents divided by their level of education, there is a statistically significant difference in the intermediate level. Subsequent comparisons, using Tukey's HSD test, indicate that the mean of Group 5: Post-graduate degrees: Master/PhD is significantly different from the mean of Group 2: Secondary Education degree, as well as the mean of Group 4. Post-secondary non-academic degrees. That is, people with the highest level of education (master/PhD) show a greater willingness to buy (influenced by Facebook promotion), compared to those with high and secondary education.

In other cases, there is no significant difference. Hence, only the hypothesis H1c was confirmed. Other hypotheses were dismissed. After determining the statistically significant difference between the mentioned groups of respondents divided by the level of education, a two-factor analysis of variance was conducted. This sought to determine whether the observed differences apply to different gender groups (men and women), as well as whether the observed differences also apply to different age groups (people younger than 26 years, those from 26 to 35 years, people from 36 to 45 years and those aged 46-65). The results of this analysis did not reach statistical significance.

The survey results allow management to perceive Facebook users as potential customers, and to understand the impact that demographic variables and Facebook usage characteristics have on them when making a purchase. On the one hand, they suggest that management should focus on those with the highest levels of education. On the other hand, it can be seen that there is a problem associated with low levels of willingness to buy in other groups of respondents, which requires further adaptation and improvement of promotional strategies. In addition to the practical contribution, the results of this research also contribute to the national literature, since related papers are predominantly concerned with the analysis of promotion through the social network Facebook, from a theoretical point of view.

In future research, it would be desirable to include some additional claims describing the purchase, in order to obtain a more comprehensive analysis. In addition, it is necessary to analyze the causes of the relatively low level of purchase (generated by the promotion through the Facebook social network). Furthermore, the impact of promotion through this network on customer loyalty could also be examined. Finally, in the studies that follow, it would be useful to survey a larger number of respondents. 
104 | ANALYSIS OF THE EFFECTS OF DEMOGRAPHIC VARIABLES AND CHARACTERISTICS OF THE FACEBOOK SOCIAL NETWORK ON PURCHASING

\section{REFERENCES}

Ajzen, I. (1991). The theory of planned behavior. Organizational Behavior And Human Decision Processes, 50(2), 179-211.

Ajzen, I., \& Fishbein, M. (1980). Understanding attitudes and predicting social behavior. Englewood Cliffs, NJ: Prentice-Hall.

Bannister, A., Kiefer, J. \& Nellums, J. (2013). College students' perceptions of and behaviours regarding Facebook advertising: an exploratory study. The Catalyst, 3(1), 1-20.

Bharati, P., Zhang, C., \& Chaudhury, A. (2014). Social media assimilation in firms: investigating the roles of absorptive capacity and institutional pressures. Information Systems Frontiers, 16(2), 257-272.

Briggs, S. R., \& Cheeks, J. M. (1986). The Role of Factor Analysis in the Development and Evaluation of Peronality Scales. Journal of Personality, 54(1), 106-148.

Chaffey, D., \& Ellis-Chadwick, F. (2019). Digital Marketing: Strategy, Implementation and Practice. Harlow: Pearson Education.

Chandra, B., Goswami, S. \& Chouhan, V. (2012). Investigating attitude towards online advertising on social media - an empirical study. Management Insight, 8(1), 1-14.

Charlesworth, A. (2014). Digital Marketing. A practical approach. NewYork: Routledge.

Chiu, C., Wang, E. T. G., Fang, Y., \& Huang, H. (2014). Understanding customers' repeat purchase intentions in $\mathrm{B} 2 \mathrm{C}$ e-commerce: the roles of utilitarian value, hedonic value and perceived risk. Information Systems Journal, 24(1), 85-114.

Cohen, J. (1988). Statistical power analysis for the behavioral sciences (2nd edition). Hillsdale, NJ: Lawrence Earlbaum Associates.

Crosman, P. (2008). Attracting young investors - financial firms are embracing mobile technology, Web 2.0 tools and social networking principles to reach Gen X and Gen Y. Wall Street and Technology, 26(1), 16.

Duffett, R. G. (2015). Facebook advertising's influence on intention-topurchase and purchase amongst Millennials. Internet Research, 25(4), 498-526.

Fairbrother, P. (2019). How To Find The Best Audiences To Target On Facebook. Retrieved from: https://adespresso.com/blog/facebookaudience-insights/ 
Field, A. (2009). Discovering Statistics using SPSS. London: Sage.

George, D., \& Mallery, P. (2003). SPSS for Windows Step by Step: A Simple Guide and Reference (4th ed.). Boston: Allyn \& Bacon.

Hair, J. F., Bush, R. P., \& Ortinau, D. J. (2009). Marketing Research. New York: McGraw Hill/Irwin.

Krstić, A., \& Đurđević, B. (2017). Marketing on social networks. Marketing, 48(4), 254-260.

Maglov, M. (2017). Truths and misconceptions about social networks. Magazine Controlling, 12, 126-129. Retrieved from: http://mcb.rs/wpcontent/uploads/2017/07/CM-12-Supply-chain.pdf

Maree, K. (2007). First Steps in Research. Pretoria: Van Schaik.

Maxwell, J. (2013). Demystifying the online shopper 10 myths of multichannel retailing. PWC's Multichannel Retail Survey, 3-35. Retrieved from: https://pwc.to/21YzUID

Mir, I. A. (2012). Consumer attitudinal insights about social media advertising: a South Asian perspective. The Romanian Economic Journal, 15(45), 265-288.

Nunnally, J. C. (1978). Introduction to Psychological Measurement. New York: McGraw-Hill.

Pallant, J. (2011). SPSS: survival manual (4th ed). Belgrade: Mikro book.

Quinton, S., \& Simkin, L. (2017). The Digital Journey: Reflected Learnings and Emerging Challenges. International Journal of Management Reviews, 19(4), 455-472.

SEMrush (2016). Social Media vs. Content: Where Should You Invest? Retrieved from:

https://www.marketingprofs.com/articles/2018/33538/10-steps-to-launcha-successful-social-media-marketing-campaign

Taylor, D. G., Lewin, J. E., \& Strutton, D. (2011). Friends, fans, and followers: do ads work on social networks. Journal of Advertising Research, 51(1), 258-275.

Treadaway, C., \& Smith, M. (2010). Facebook Marketing: An Hour a Day. Indianapolis, Indiana: Wiley Publishing, Inc.

Vătămănescu, E. M., Nistoreanu, B. G., \& Mitan, A. (2017). Competition and Consumer Behavior in the. Context of the Digital Economy. Amfiteatru Economic, 19(45), 354-366. 
106 | ANALYSIS OF THE EFFECTS OF DEMOGRAPHIC VARIABLES AND CHARACTERISTICS OF THE FACEBOOK SOCIAL NETWORK ON PURCHASING

Wang, Y., \& Sun, S. (2010). Assessing beliefs, attitudes, and behavioural responses toward online advertising in three countries. International Business Review, 19(1), 333-344.

Wolin, L. D., Korgaonkar, P., \& Lund, D. (2002). Beliefs, attitudes and behaviour towards web advertising. International Journal of Advertising, 21(1), 87-113.

Yang, T. (2012). The decision behaviour of Facebook users. Journal of Computer Information Systems, 52(3), 50-59.

Yoo, C. Y., Kim, K., \& Stout, P. A. (2010). Assessing the effects of animation in online banner advertising: hierarchy effects model. Journal of interactive advertising, 4(2), 49-60.

Delivered: 13.07.2019. Accepted: 28.11.2019. 